[Radiocarbon, Vol 23, No. 2, 1981, P 305-321]

\title{
US GEOLOGICAL SURVEY, MENLO PARK, CALIFORNIA, RADIOCARBON MEASUREMENTS II
}

\section{STEPHEN W ROBINSON and DEBORAH A TRIMBLE}

\author{
US Geological Survey, Menlo Park, California 94025
}

The Menlo Park radiocarbon laboratory of the US Geological Survey began operation in January 1976 in a new building with a counting room $9.8 \mathrm{~m}$ below the ground surface. Shielding above the counters consists of $30 \mathrm{~cm}$ lead and $8.2 \mathrm{~m}$ earth. The ionizing cosmic ray flux at the counters is $0.28 \mathrm{cpm} / \mathrm{cm}^{2}$. Background levels obtained thus far are summarized in Table 1.

In the first date list from this laboratory (Robinson, 1977) marine shell dates were reported without a stated reservoir age correction, but with an implied reservoir age correction of 412 years because the results were not normalized to $\delta^{13} \mathrm{C}=-25 \%$. We have now determined (Table 2; Robinson and Thompson, 1980) applicable reservoir ages for the west coast of the United States and Mexico:

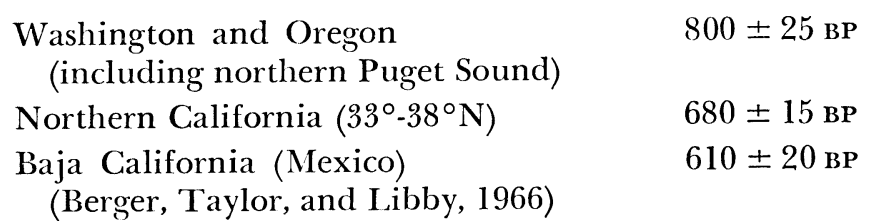

In the absence of other published guidelines, we will henceforth follow the recommendations of Stuiver and Polach (1977) in reporting marine shell dates. Table 3 presents the reservoir-corrected results for the seven marine shell dates reported in USGS I (Robinson, 1977).

The dates in this list are calculated using the 5570-yr half-life, and published standard deviations include only counting statistics. The additional uncertainty due to isotopic fractionation, counter pressure, temperature, and voltage is about \pm 30 years if $\delta^{13} \mathrm{C}$ of the counted gas was not measured.

\section{ACKNOWLEDGMENTS}

The authors gratefully acknowledge the technical assistance of Carol Yamate, Eric Blommer, John LeLange, Karey Gladman, and Rod Moseley in sample preparation and laboratory maintenance.

\section{United States}

California

\section{USGS-182. Pt Reyes National Sea Shore, Est $\delta^{13} C=-25 \%$ Marin Co}

Fine-grained marsh sediments rich in organic material from Religion Colony landslide $\left(38^{\circ} 57.5^{\prime} \mathrm{N}, 122^{\circ} 36^{\prime} \mathrm{W}\right)$. Date is $\mathrm{min}$ for sliding. Coll in 1977 by David Wagner, California Div Mines and Geology; subm by Edward Helley, USGS. 
Pine Valley series, San Diego Co

Charcoal from sec $4 \mathrm{~m}$ thick of valley-filling alluvium cut by Pine Valley Creek $\left(32^{\circ} 50^{\prime} 13^{\prime \prime} \mathrm{N}, 116^{\circ} 32^{\prime} 02^{\prime \prime} \mathrm{W}\right)$, ca $1.5 \mathrm{~m}$ above present stream level. With USGS-96, dates deposition of extensive stream terraces and gives approx rate of dissection. Coll and subm by W C Hoggatt, USGS.

USGS-298.

Ca $1.5 \mathrm{~m}$ above present stream level.

USGS-96.

Ca $0.5 \mathrm{~m}$ above present stream level.
$860 \pm 50$ Est $\delta^{19} \mathrm{C}=-25 \%$ o

$$
920 \pm 60
$$

Est $\delta^{15} \mathrm{C}=-25 \%$ o

\section{Pallett Creek series, near Valyermo}

Samples from sec $8 \mathrm{~m}$ thick of peat, silt, sand, and gravel broken and deformed by San Andreas fault ( $34^{\circ} 27.4^{\prime} \mathrm{N}, 117^{\circ} 51.7^{\prime} \mathrm{W}$ ) (Sieh, 1978). Coll in 1976 and subm by Kerry Sieh, California Inst Technol.

USGS-144.

$190 \pm 50$

Peat from Unit 81 , Exposure 11 , ca $1.3 \mathrm{~m}$ below ground surface. Deposition preceded large earthquake Event X.

USGS-136.

$460 \pm 60$

Peat from Unit 72 , Exposure 11, ca $1.8 \mathrm{~m}$ below ground surface. Deposition immediately postdates large earthquake Event V.

USGS-137.

$320 \pm 60$

Peat from upper 1 to $2 \mathrm{~cm}$ of Unit 68 , Exposure 11, ca $2.4 \mathrm{~m}$ below ground surface. Deposition immediately antedates large earthquake Event V.

USGS-84.

$800 \pm 60$

Peat from lower half of Unit 61, Exposure 1, ca $1.8 \mathrm{~m}$ below ground surface. Deposition preceded large earthquake Event $T$.

TABLE 1

Counter characteristics

\begin{tabular}{cccc}
\hline $\begin{array}{c}\text { Volume } \\
(1)\end{array}$ & $\begin{array}{c}\mathrm{CO}_{2} \\
\text { pressure } \\
(\mathrm{atm})\end{array}$ & $\begin{array}{c}\text { Net modern } \\
\text { count rate } \\
(\mathrm{cpm})\end{array}$ & $\begin{array}{c}\text { Background } \\
\text { count rate } \\
(\mathrm{cpm})\end{array}$ \\
\hline 0.125 & 2.72 & 2.6 & 0.19 \\
0.40 & 2.72 & 7.2 & 0.33 \\
0.65 & 2.72 & 10.6 & 0.39 \\
1.04 & 2.50 & 16.6 & 0.50 \\
1.22 & 2.62 & 20.2 & 0.81 \\
2.47 & 1.89 & 30.1 & 1.38 \\
2.47 & 2.89 & 44.0 & 1.20 \\
2.92 & 2.72 & 53.8 & 1.98 \\
\hline
\end{tabular}


Survey, Menlo Park, California, Radiocarbon Measurements II 307

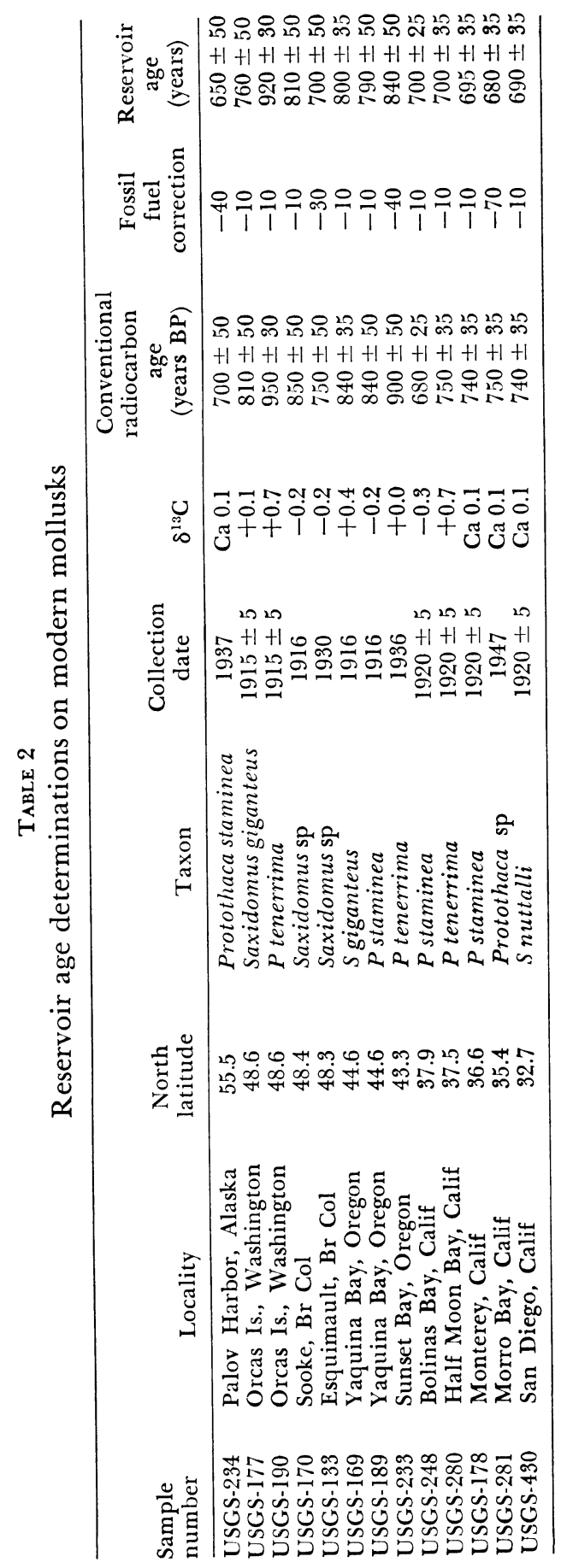




\section{USGS-83.}

$1130 \pm 45$

Peat from Unit 49 , Exposure 1 , ca $2.3 \mathrm{~m}$ below ground surface. Deposition postdated earthquake Event I.

\section{USGS-82.}

$1020 \pm 50$

Peat from $2 \mathrm{~cm}$ of Unit 47 , Exposure 1 ca $2.5 \mathrm{~m}$ below ground surface. Deposition immediately postdates earthquake Event I.

\section{USGS-138.}

$1130 \pm 70$

Clayey peat from upper $1 \mathrm{~cm}$ of Unit 45 , Exposure 11 , ca $3.8 \mathrm{~m}$ below ground surface. Deposition immediately preceded earthquake Event I.

\section{USGS-139.}

$1160 \pm 60$

Clayey peat of Unit 41, Exposure 11, ca $4 \mathrm{~lm}$ below ground surface. Deposition postdates large earthquake Event $\mathrm{F}$.

\section{USGS-141.}

$1460 \pm 60$

Clayey peat (ca $1 \mathrm{~cm}$ thick) of Unit 36 , Exposure 11 , ca $4.0 \mathrm{~m}$ below ground surface. Deposition postdates earthquake Event D.

\section{USGS-140.}

$1410 \pm 50$

Clayey peat ( $2 \mathrm{~cm}$ thick) of Unit 33 , Exposure $11,5.0 \mathrm{~m}$ below ground surface. Deposition antedated Event D.

\section{USGS-142.}

$1830 \pm 50$

Lower ca $2 \mathrm{~cm}$ of clayey peat, $10 \mathrm{~cm}$ thick, of Unit 26, Exposure 11, ca $5.8 \mathrm{~m}$ below ground surface. Oldest horizon sampled in excavations at Pallett Creek.

\section{La Honda Creek Landslide series}

Wood from borehole samples within landslide, $2.8 \mathrm{~km} \mathrm{~N}$ of $\mathrm{La}$ Honda $\left(37^{\circ} 21^{\prime} \mathrm{N}, 122^{\circ} 17^{\prime} \mathrm{W}\right)$. The most recent of these samples indi-

TABLE 3

Reservoir corrections for marine shell dates previously reported

\begin{tabular}{cccc}
\hline Sample no. & $\begin{array}{c}\text { Conventional } \\
\text { age }\end{array}$ & $\begin{array}{c}\text { Reservoir } \\
\text { correction }\end{array}$ & $\begin{array}{c}\text { Reservoir } \\
\text { corrected age }\end{array}$ \\
\hline USGS-7 & $3670 \pm 80$ & $800 \pm 25$ & $2870 \pm 90$ \\
USGS-65 & $6290 \pm 70$ & $800 \pm 25$ & $5490 \pm 80$ \\
USGS-64 & $12689 \pm 99$ & $800 \pm 25$ & $12280 \pm 100$ \\
USGS-71 & $1570 \pm 69$ & $680 \pm 15$ & $890 \pm 60$ \\
USGS-72 & $6860 \pm 100$ & $680 \pm 15$ & $6180 \pm 100$ \\
USGS-35 & $3480 \pm 97$ & $680 \pm 15$ & $2800 \pm 90$ \\
USGS-36 & $5240 \pm 139$ & $680 \pm 15$ & $4560 \pm 130$ \\
\hline
\end{tabular}


cates landslide occurred not more than $3770 \pm 150$. Coll in 1976 and 1977 and subm by G Wieczorek, USGS.

\section{USGS-147. 10.7 to $11 \mathrm{~m}$}

USGS-149. 8.4 to $9.1 \mathrm{~m}$

USGS-326. 9.1 to $9.8 \mathrm{~m}$

USGS-391. 8.5 to $9.5 \mathrm{~m}$

USGS-160. The Geysers
$3990 \pm 70$

Est $\delta^{13} C=-25 \%$ o

$4170 \pm 140$

Est $\delta^{13} \mathrm{C}=-25 \%$ o

$3770 \pm 150$

Est $\delta^{13} \mathrm{C}=-25 \%$ o

$4000 \pm 35$

Est $\delta^{13} \mathrm{C}=-25 \%$ o

$13,200 \pm 160$

Est $\delta^{13} C=-25 \%$ o

Carbonized wood in base of colluvium from depth 12 to $17 \mathrm{~m}$ in

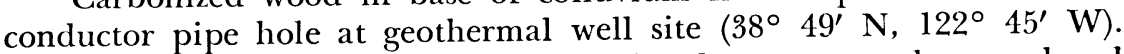
Date is min for landslide induced rotational movement that produced closed depression in which colluvium accumulated. Coll 1976 by C Isselhardt and D McMurdie, Union Oil Co; subm by $\mathrm{R} J$ McLaughlin, USGS.

\section{Bolinas Lagoon series Marine Co}

Samples from Borehole 4 on Bolinas Lagoon Spit $\left(37^{\circ} 54^{\prime} \mathrm{N}, 122^{\circ}\right.$ $\left.39^{\prime} \mathrm{W}\right)$. Coll and subm 1976 by J Bergquist and B Atwater, USGS.

\section{USGS-171. Bolinas Lagoon}

$\mathbf{7 7 7 0} \pm \mathbf{7 0}$

Oyster shells (Ostrea lurida) $32.5 \mathrm{~m}$ below present mean sea level. Reservoir corrected age: $7090 \pm 65$. Dates most recent marine transgression and indicates magnitude of tectonic subsidence of Bolinas Lagoon graben.

\section{USGS-172. Bolinas Lagoon}

$8400 \pm 100$

Fibrous peat from lacustrine clayey silt $36 \mathrm{~m}$ below present mean sea level. Dates fresh water environment in area of present marine inundation and indicates magnitude of tectonic displacement of Bolinas Lagoon graben.

\section{USGS-224. Bolinas Lagoon}

$\mathbf{8 8 0 0} \pm \mathbf{8 0}$

Fibrous peat from lacustrine clayey silt $41 \mathrm{~m}$ below present mean sea level. Dates spruce pollen (Picea sitchensis) that indicates climate significantly cooler and wetter than at present. Indicates magnitude of tectonic subsidence of Bolinas Lagoon graben.

USGS-220. Santa Rosa, California

$4370 \pm 120$

$$
\text { Est } \delta^{13} C=-25 \% \text { o }
$$

Charcoal from trench along left bank of Santa Rosa Creek $\left(38^{\circ} 26^{\prime}\right.$ $\mathrm{N}, 122^{\circ} 42^{\prime} \mathrm{W}$ ). Sample provides absolute age control of alluvium 
involved in last active faulting at trench locality. Coll 1977 by T D Hayes; subm by Ed Helley and Darrell Herd, USGS.

\section{USGS-221. Placer County}

$1710 \pm 60$ (38 $57^{\prime} 47^{\prime \prime} \mathrm{N}, 121^{\circ} 07^{\prime} 51^{\prime \prime} \mathrm{W}$ ). Sample provides age of 1 on fault within Foothills fault system. Coll 1977 by Glenn Borcherat and Richard Hilborne, California Div Mines and Geol; subm by Ed Helley.

\section{USGS-173. Butano Creek, San Mateo Co}

$>42,900$

Wood in peaty clays exposed in roadcut on $\mathrm{E}$ side of Cloverdale $\mathrm{Rd}$ $\mathrm{E}$ of Butano Creek ( $\left.37^{\circ} 14^{\prime} 15^{\prime \prime} \mathrm{N}, 122^{\circ} 21^{\prime} 55^{\prime \prime} \mathrm{W}\right)$. Date is min for old alluvium of Butano Creek. Coll in 1977 by K R Lajoie and G E Weber, Univ California, Santa Cruz; subm by K R Lajoie, USGS.

\section{USGS-285. Tanner Bank, Southern California Borderland \\ $4150 \pm 130$
Est $\delta^{13} C=0 \%$ o}

Marine shell hash coll from submerged strandline $60 \mathrm{~m}$ below sea level on Tanner Bank (32 $\left.44^{\prime} 49^{\prime} \mathrm{N}, 119^{\circ} 08^{\prime} 49^{\prime \prime} \mathrm{W}\right)$. Reservoir corrected age: $3470 \pm 130$. Sample helps estimate Holocene rise in sea level in Southern California Borderland region. Coll 1975 by C L Barton, Univ Southern California; subm by K R Lajoie.

\section{USGS-287. Point Año Nuevo \\ $\mathbf{3 9 , 5 0 0} \pm \mathbf{6 5 0}$}

Marine shells (Saxidomus giganteus, Deshayes, id by $\mathrm{C}$ W $\mathrm{H}=0 \%$ from marine terrace at Point Año Nuevo $\left(37^{\circ} 06^{\prime} 51^{\prime \prime} \mathrm{N}, 122^{\circ} 19^{\prime} 51^{\prime \prime} \mathrm{W}\right)$. Amino-acid and paleontologic data indicate sample is Sangamonian in age (85Ka-105Ka). Sample was dated to determine ${ }^{14} \mathrm{C}$ activity in shell known to be beyond range of ${ }^{14} \mathrm{C}$. Coll 1956 by C W Hoskins; subm by K R Lajoie.

\section{USGS-288. Goleta}

$40,300 \pm 950$ Est $\delta^{1 s} C=0 \%$

Marine shell (Saxidomun nuttalli Conrad, id. by G L Kennedy) in growth position from marine terrace at Goleta, Santa Barbara Co $\left(34^{\circ}\right.$ $\left.24^{\prime} 33^{\prime \prime} \mathrm{N}, 119^{\circ} 15^{\prime} 42^{\prime \prime} \mathrm{W}\right)$. Sample yields amino-acid age estimate of approx 40,000 yr BP. Coll 1977 by K R Lajoie, G L Kennedy, J F Wehmiller, and S A Mathieson; subm by $\mathrm{K}$ R Lajoie.

\section{USGS-289. Lake Cahuilla, Lower Borrego Valley \\ $1030 \pm 40$ \\ Est $\delta^{13} C=+2.38 \%$ o}

Non-marine pelecypod shells (Anodonta sp) from youngest deposit of Holocene high-stand of Lake Cahuilla, $9 \mathrm{~km}$ SE of Ocotillo Wells $\left(33^{\circ}\right.$ $\left.05.4^{\prime} \mathrm{N}, 116^{\circ} 02.9^{\prime} \mathrm{W}\right)$. All shells were articulated and coll from surface of deposit. Dated to check W-2456 (860 \pm 200$)$ (Clark, Grantz, and Rubin, 1972) from same sample. Coll and subm by Malcolm Clark, USGS. 
USGS-211. Auburn Damsite, Auburn Est $\delta^{13} \mathrm{C}=-25 \%$

Wood fragments $90 \mathrm{~cm}$ below surface in backhoe trench $\left(38^{\circ} 52.5^{\prime}\right.$ $\left.\mathrm{N}, 121^{\circ} 04^{\prime} \mathrm{W}\right)$. Colluvium in which wood fragments were found was offset and should place age of activity on East March fault zone. Coll by R T Kilbourne, California Dept Mines and Geol; subm by Ed Helley.

USGS-191. Auburn Damsite, Auburn

$300 \pm 40$

Charcoal sample 30 to $50 \mathrm{~cm}$ below surface in backhoe trench BHT-1 $\left(38^{\circ} 52^{\prime} 30^{\prime \prime} \mathrm{N}, 121^{\circ}, 03^{\prime \prime} \mathrm{W}\right)$. Sample dates colluvium which is vital to all fault studies in Foothill fault system. Coll 1977 by Ed Helley, Dave Harwood, and Denis Marchand; subm by Ed Helley.

Alaska

Upper Turnagain Arm series, Portage

Artificially concentrated organic debris from unconsolidated silt in subsurface, Portage $\left(60^{\circ} 49^{\prime} \mathrm{N}, 148^{\circ} 59^{\prime} \mathrm{W}\right)$. Age/depth relations will show rate of sediment accumulation in Turnagain Arm fiord. Coll 1975 by A T Ovenshine, R Kachadoorian, and S Bartsch-Winkler subm by $S$ Bartsch-Winkler, USGS.

USGS-126. $15-17 \mathrm{~m}$ $\begin{aligned} & \mathbf{5 7 4 0} \pm \mathbf{1 9 0} \\ & \text { Est } \delta^{1 s} C=-25 \% 0 \\ & \mathbf{6 4 9 0} \pm \mathbf{2 2 0} \\ & \text { Est } \delta^{1 s} C=-25 \% \text { o }\end{aligned}$

USGS-154. 50-51m

USGS-228. $67 \mathrm{~m}$ Est $\delta^{13} C=-25 \%$

USGS-127. 92-93m

$8230 \pm 100$ Est $\delta^{1 s} C=-25 \%$ o

$\mathbf{3 1 8 0} \pm \mathbf{5 0}$

USGS-108. Kodiak Shelf, Alaska

Est $\delta^{1 s} C=-25 \%$

Broken marine shells from gravelly sand on N Albatross Bank, W Gulf of Alaska $\left(57^{\circ} 45.80^{\prime} \mathrm{N}, 151^{\circ} 08.05^{\prime} \mathrm{W}\right)$. Reservoir-corrected age: $2530 \pm 70$. Shells probably broken by shoreline processes during last Pleistocene transgression, rather than in modern setting. Coll and subm in 1976 by M A Hampton, USGS.

\section{Prudhoe Bay Borehole series}

Boreholes were drilled during Spring 1976 and 1977, to determine distribution of ice-bonded permafrost, to establish history of local relative sea level, and to determine character of surficial materials of continental shelf on Beaufort Sea (Barnes and Hopkins, 1978; Hopkins, 1977; Hopkins and Hartz, in press; Sellmann and Chamberlain, in press). A sled-mounted drill on the shorefast ice was used as a drilling platform. Coll and subm 1977 by D M Hopkins, USGS. 
USGS-132. Borehole PB-1, 7.8m bsl

$490 \pm 90$

Wood fragments from silty clay at depth $7.8 \mathrm{~m}$ bsl. Sample underlies $3.8 \mathrm{~m}$ marine silt in borehole PB-1 drilled in water $4 \mathrm{~m}$ deep at center of Prudhoe Bay $\left(70^{\circ} 24.9^{\prime} \mathrm{N}, 148^{\circ} 19.3^{\prime} \mathrm{W}\right)$. Prudhoe Bay is believed to have originated as thermokarst lake breached by retreating marine shoreline. Sample indicates former lake was breached and invaded by sea a little earlier than $500 \mathrm{yr}$ ago.

\section{USGS-192. Borehole PB-2, $13.7 \mathrm{~m}$ bsl}

$$
18,000 \pm 170
$$

Organic carbon in bulk sediment of overconsolidated clay and silt ca $13.7 \mathrm{~m}$ bsl, drilled in borehole PB-2 $\left(70^{\circ} 30.6^{\prime} \mathrm{N}, 140^{\circ} 18.0^{\prime} \mathrm{W}\right)$. Overconsolidated marine silt and clay are thought, based on pollen and foraminifers, to be of Sangamon interglacial age. Age determination of $18,000 \mathrm{yr}$ is incompatible with pollen and foraminiferal content and with presence of shallow ice-bonded permafrost at this site. Evidently, it reflects undetected presence of admixture of Holocene detrital organic material introduced by bioturbation into Sangamon marine clay.

\section{USGS-210. Borehole PB-3, 49m bsl}

$>33,900$

Twigs and organic fragments hand picked from peaty sand from core recovered at $49 \mathrm{~m}$ bsl $\left(70^{\circ} 25.8^{\prime} \mathrm{N}, 148^{\circ} 26.6^{\prime} \mathrm{W}\right)$. Data from all boreholes suggest sandy and gravelly alluvium from which USGS-210 was recovered is of middle Pleistocene age and much older than material dated in PB-7, 42,800 $\pm 1440 \mathrm{yr}$ old (USGS-249). True age of this small sample is probably much greater than $34,000 \mathrm{yr}$.

\section{USGS-249. Borehole PB-7, 12.2-13.6m bsl Est $\delta^{13} C=-25 \%$}

Twigs and organic fragments from peaty sand washed up from depth 13.3 to $13.6 \mathrm{~m}$ bsl $\left(70^{\circ} 24.2^{\prime} \mathrm{N}, 148^{\circ} 33.5^{\prime} \mathrm{W}\right)$. Organic horizon represented by USGS-249 was also intersected in borehole OH-3370, drilled in 1975 by Osterkamp and Harrison (1976). Very small sample of twigs recovered from same level in OH-3370 was reported at 22,300 \pm $1100 \mathrm{yr}$ old (AU-115) (M S Young, written commun, 1976). Our larger sample probably gives better estimate of true age of buried peaty sand in PB-7 and OH-3370.

\section{USGS-155. Northern Bering Sea}

$13,200 \pm 110$

Peat, rootlets, wood, and nut fragments from $79 \mathrm{~cm}$ depth taken in sediment ca $34 \mathrm{~m}$ below msl, $20 \mathrm{~km}$ NE of King I. $\left(65^{\circ} 05^{\prime} \mathrm{N}\right.$, $\left.167^{\circ} 43^{\prime} \mathrm{W}\right)$. Date from peat in freshwater mud layer underlying trough between two large sand ridges on Bering epicontinental shelf. Helps date history of Holocene sea-level transgression. Coll and subm 1976 by Hans Nelson, USGS. 
USGS-156. Northern Bering Sea

Peat from $175 \mathrm{~cm}$ depth in core taken in sediment ca $31 \mathrm{~m}$ below $\mathrm{msl}, 29 \mathrm{~km} \mathrm{NE}$ of King I. $\left(65^{\circ} 08^{\prime} \mathrm{N}, 167^{\circ} 36^{\prime} \mathrm{W}\right)$. Date from peat in freshwater mud layer underlying trough that chronicles history of scour and/or nondeposition. Coll and subm 1976 by Hans Nelson.

\section{USGS-157. Northern Bering Sea}

$16,400 \pm 430$

Peat, wood fragments, and twigs from $83 \mathrm{~cm}$ depth in sediment core from ca $28 \mathrm{~m}$ below msl, $31 \mathrm{~km} \mathrm{NE}$ of King I. $\left(65^{\circ} 08^{\prime} \mathrm{N}, 167^{\circ} 33^{\prime} \mathrm{N}\right)$. Sample, peaty silt in freshwater layer on flank of shoal on Bering Shelf dates pre-transgressive sediment; helps establish Holocene sedimentation rate and history of sea-level rise. Coll and subm 1976 by Hans Nelson.

\section{USGS-158. Central Norton Sound}

$\mathbf{2 9 , 5 0 0} \pm \mathbf{3 4 0}$

Peat from $175 \mathrm{~cm}$ depth in core taken in sediment ca $17 \mathrm{~m}$ below msl, $135 \mathrm{~km} \mathrm{SE}$ of Nome $\left(63^{\circ} 53^{\prime} \mathrm{N}, 163^{\circ} 01^{\prime} \mathrm{W}\right)$. Sample, peat in freshwater silt dates possible mid-Wisconsin transgression and provides sedimentation rate for late Pleistocene emergence. Coll and subm by Hans Nelson.

\section{USGS-159. Northeastern Norton Sound}

$$
\begin{array}{r}
11,800 \pm 200 \\
\text { Est } \delta^{13} C=-25 \% \text { o }
\end{array}
$$

Peat and wood fragments from $132 \mathrm{~cm}$ depth in core taken in sediment ca $14 \mathrm{~m}$ below msl, $95 \mathrm{~km}$ NNE of Stuart I. (64 $\left.24^{\prime} \mathrm{N}, 161^{\circ} 49^{\prime} \mathrm{W}\right)$. Date from peaty silt indicates history of Holocene sea-level transgression and provides Holocene sedimentation rate. Coll and subm by Hans Nelson.

\section{USGS-183. Northern Bering Sea}

$$
2090 \pm 120
$$

Wood fragments from top $15 \mathrm{~cm}$ of box core taken in sediment ca $18 \mathrm{~m}$ below msl, $168 \mathrm{~km} \mathrm{~S}$ of Nome $\left(62^{\circ} 59^{\prime} \mathrm{N}, 165^{\circ} 34^{\prime} \mathrm{W}\right)$. Sample, $45 \mathrm{~km}$ from Yukon Delta dates storm sand layer and gives sedimentation rate of Yukon R prodelta sediments. Coll and subm in 1976 by Hans Nelson.

\section{USGS-186. Colville River}

$38,300 \pm 1300$ Est $\delta^{13} C=-25 \%$ o

Detrital peat $8 \mathrm{~m}$ below top of sec $16 \mathrm{~m}$ thick of sand and gravelly sand of Gubik Formation. Gubik deposits cap bluff $25.6 \mathrm{~m}$ high, above Colville $\mathrm{R}\left(70^{\circ} 04.35^{\prime} \mathrm{N}, 151^{\circ} 22.9^{\prime} \mathrm{W}\right)$. Date believed too young and will be checked by dating detrital wood coll at same stratigraphic horizon. Coll 1975 and subm 1977 by L D Carter, USGS.$$
1350 \pm 50
$$

USGS-188. Colville River Est $\delta^{13} C=-25 \%$

Peat from buried organic horizon $30 \mathrm{~cm}$ thick underlying $90 \mathrm{~cm}$ silty sand and $30 \mathrm{~cm}$ modern turf. Exposed in bluff on Colville R $\left(70^{\circ} 05.3^{\prime} \mathrm{N}\right.$,
} 
$\left.151^{\circ} 24.8^{\prime} \mathrm{W}\right)$. Date indicates peat is not correlative with Holocene paleosol that occurs elsewhere on Arctic Coastal Plain (Carter and Robinson, 1978). Coll 1975 and subm 1977 by L D Carter.

USGS-208. Colville River

Est $\delta^{1 . s} C=-25 \%$ o

Spruce (Picea mariana) log from autochthonous peat (paleosol) $3 \mathrm{~m}$ above base of sec $12.8 \mathrm{~m}$ thick of sand and gravelly sand of Gubik Formation. Gubik deposits cap bluff, $33.5 \mathrm{~m}$ high, on Colville $\mathrm{R}\left(70^{\circ}\right.$ $05^{\prime} \mathrm{N}, 151^{\circ} 24^{\prime} \mathrm{W}$.). Spruce needles found in peat indicate tree was either growing at site or had not been transported far. Date indicates spruce trees were growing on or near Arctic Coastal Plain during Quaternary sometime before 45,000 yr ago. Coll 1975 and subm 1977 by L D Carter.

\section{USGS-184. Colville River}

$8180 \pm 80$ Peat from middle of buried organic horizon $75 \mathrm{~cm}$ thick underlying $70 \mathrm{~cm}$ silty sand and $30 \mathrm{~cm}$ modern turf. Peat is exposed in bluff along Colville $\mathrm{R}\left(70^{\circ} 04.35^{\prime} \mathrm{N}, 151^{\circ} 22.9^{\prime} \mathrm{W}\right)$. Date suggests peat is correlative with Holocene paleosol occuring elsewhere on Arctic Coastal Plain (Carter and Robinson, 1978). Coll 1975 and subm 1977 by L D Carter.

\section{USGS-185. Colville River}

$\mathbf{2 2 8 0} \pm \mathbf{5 0}$

Peat USGS-184 $\left(70^{\circ} 04.35^{\prime} \mathrm{N}, 151^{\circ} 229^{\prime} \mathrm{W}\right)$ thick in sec described for vegetative cover at this locality. Coll 1975 and subm 1977 by L D Carter.

\section{USGS-187. Kogosukruk River}

$$
3740 \pm 60
$$

\section{iver 800} depos expose $4.6 \mathrm{~m}$ high of fluvial terrace eposits along Kogosukruk R $\left(69^{\circ} 50.1^{\prime} \mathrm{N}, 151^{\circ} 35^{\prime} \mathrm{W}\right)$. Terrace separates Kogosukruk and Colville Rivers S of Sentinel Hill. Sample dates this abandoned flood plain. Coll 1975 and subm 1977 by L D Carter.

\section{USGS-205. Umiat}

$3850 \pm 45$

Wood coll $2.4 \mathrm{~m}$ below top alluvial to river bluff $6.4 \mathrm{~m}$ high on Colville $\mathrm{R}$ near Umiat $\left(69^{\circ} 229^{\prime} \mathrm{R}\right.$, exposed in W). Sample dates this abandoned flood plain. Coll 1975 and subm 1977 by L D Carter.

\section{USGS-206. Liscum Slough} $100 \pm 60$
$C=-25 \%$ 。 tion exposed in cut-bank of $\mathrm{Liscum}$ Base Base of stump is $1.2 \mathrm{~m}$ below top of bank and natural levee rises $1 \mathrm{~m}$ above bank top. Date records amount of alluviation in valley containing Liscum Slough since death of tree. Coll 1976 and subm 1977 by L D Carter.
} 


\section{USGS-207. Salcha River}

$$
\begin{array}{r}
\mathbf{8 2 7 0} \pm \mathbf{1 5 0} \\
\text { Est } \delta^{13} C=-25 \% \text { o }
\end{array}
$$

Detrital wood coll ca $1.5 \mathrm{~m}$ above base of river bluff $22.8 \mathrm{~m}$ high on Salcha R $\left(64^{\circ} 39.6^{\prime} \mathrm{N}, 145^{\circ} 47.25^{\prime} \mathrm{W}\right)$. Bluff was cut into alluvium and colluvium of valley tributary to Salcha $R$. Date indicates that ca $21.3 \mathrm{~m}$ of alluvium and colluvium were deposited at this site in past $8000 \mathrm{yr}$. Coll 1976 and subm 1977 by I. D Carter.

USGS-209. Tanana Valley

$$
\begin{array}{r}
\mathbf{4 5 , 8 0 0}+\mathbf{4 5 0 0} \\
-\mathbf{3 4 0 0} \\
\text { Est } \delta^{13} C=-25 \% \text { o }
\end{array}
$$

Wood from thin paleosol $9.4 \mathrm{~m}$ base of streamcut $21 \mathrm{~m}$ high near head of an alluvial fan. Fan occurs $\mathrm{S}$ of Fairbanks, at $\mathrm{N}$ margin of Alaska Range foothills $\left(64^{\circ} 04.5^{\prime} \mathrm{N}, 147^{\circ} 22.1^{\prime} \mathrm{W}\right)$. Paleosol overlies massive cobble to boulder gravel and is overlain by poorly stratified pebble to cobble gravel. Paleosol records hiatus in fan deposition that may correspond to Wisconsinan interstadial. Large error on date indicates that radiocarbon level was close to limit of detection and date may represent only a lower limit on true age of sample. Coll and subm 1976 by L D Carter.

\section{USGS-174. Delta River}

$$
120 \pm 45
$$

Est $\delta^{13} C=-25 \%$ o

Wood from base of gravelly slopewash $1 \mathrm{~m}$ thick buried beneath $2 \mathrm{~m}$ silt. Deposits mantle bluff along Delta R (63 $\left.52^{\prime} \mathrm{N}, 145^{\circ} 57.1^{\prime} \mathrm{W}\right)$. Date records time since Delta $\mathrm{R}$ flowed against bluff face. Coll and subm 1976 by L D Carter.

\section{USGS-175. Dry Creek}

Wood from buried alluvial gravel, $4 \mathrm{~m}$ below top of deposit. Gravel forms lower $6.7 \mathrm{~m}$ of river bluff $14 \mathrm{~m}$ high on Dry Creek, $\mathrm{S}$ of Fairbanks $\left(64^{\circ} 21.8^{\prime} \mathrm{N}, 147^{\circ} 18.5^{\prime} \mathrm{W}\right)$. Upper $3 \mathrm{~m}$ of gravel is thoroughly weathered and contains ice-wedge pseudomorphs, overlain successively by 2 to $3 \mathrm{~m}$ silt, $3 \mathrm{~m}$ sandy gravel and $1 \mathrm{~m}$ silt. Date indicates gravel antedates midWisconsinan. USGS-176 suggests that weathering profile at top of gravel also is older than mid-Wisconsinan and, thus, must be Sangamonian or older. Coll and subm 1976 by L D Carter.

\footnotetext{
USGS-176. Dry Creek

Est $\delta^{1 s} \mathrm{C}=-25 \%$ 。

Small stems coll near base of deposit of eolian silt, $3 \mathrm{~m}$ thick, exposed in river bluff $14 \mathrm{~m}$ high on Dry Creek $\left(64^{\circ} 21.8^{\prime} \mathrm{N}, 145^{\circ} 57.1^{\prime} \mathrm{W}\right)$. Silt overlies $6.7 \mathrm{~m}$ alluvial gravel and is overlain successively by $3 \mathrm{~m}$ sandy gravel and $1 \mathrm{~m}$ silt. Silt is gray at base and grades upward through mottled zone to brown at top. Date, with USGS-175, shows that deposits exposed in bluff represent considerable interval of pre-late Wisconsinan time and may prove to be important site for paleo-environmental studies. Coll and subm 1976 by L D Carter.
} 


\section{USGS-56. Sagavanirktock Valley}

$$
>49,500
$$
wedges, exposed in of gray silt overlying till and intersected by ice Shows that till, of Itkillik I age (Hamilton and Porter, 1975), antedates classical Wisconsin glacial max. Coll 1974 and subm 1976 by T D Hamilton, USGS.

\section{USGS-374. Chandalar bluffs}

$4170 \pm 45$

Silty peat overlain by $0.45 \mathrm{~m}$ frost-churned stony silt, $\mathrm{N}$ side Chandalar R near Funchion Creek $\left(67^{\circ} 07^{\prime} \mathrm{N}, 147^{\circ} 34^{\prime} \mathrm{W}\right)$. Dates episode of middle Holocene peat formation followed by intensified frost activity (Hamilton, 1979). Coll and subm 1976 by T D Hamilton.

\section{USGS-376. Mosquito Fork}

$5370 \pm 90$

Wood from buried forest bed near base of cutbank along Mosquito Fork Koyukuk R $\left(67^{\circ} 30^{\prime} \mathrm{N}, 149^{\circ} 55^{\prime} \mathrm{W}\right)$. Represents episode of stability during alluviation of $8.5 \mathrm{~m}$ terrace (Hamilton, 1979). Coll and subm 1976 by $\mathrm{T} \mathrm{D}$ Hamilton.

\section{USGS-410. North Fork bluffs}

$$
\begin{array}{r}
\mathbf{5 0 , 1 0 0}+\mathbf{3 2 0 0} \\
-\mathbf{2 6 0 0} \\
\text { Est } \delta^{1 s} C=-25 \%
\end{array}
$$

Detrital wood from oxidized gravel beneath till, near mouth of North Fork Koyukuk R $\left(67^{\circ} 07^{\prime} \mathrm{N}, 150^{\circ} 55^{\prime} \mathrm{W}\right)$. Places limiting max age on Itkillik I glaciation of Koyukuk Valley (Hamilton and Porter, 1975). Coll and subm in 1977 by T D Hamilton.

\section{USGS-412. John Valley}

$$
9890 \pm 80
$$

Wood fragments from peat bed near base of $16 \mathrm{~m}$ bluff along John $\mathrm{R}$ at $\mathrm{S}$ flank of Brooks Range $\left(67^{\circ} 07^{\prime} \mathrm{N}, 151^{\circ} 52^{\prime} \mathrm{W}\right)$. Dates early phase of filling of depositional basin in front of end moraine of Itkillik II age (Hamilton and Porter, 1975). Coll and subm 1977 by T D Hamilton.

\section{USGS-413. Sixtymile Creek}

$$
\begin{array}{r}
\mathbf{2 7 , 7 0 0} \pm \mathbf{9 5 0} \\
\text { Est } \delta^{13} C=-25 \%
\end{array}
$$

Wood fragments $40 \mathrm{~m}$ above modern river level in $70 \mathrm{~m}$ alluvium, $S$ side Sixtymile Creek (67 $\left.21^{\prime} \mathrm{N}, 152^{\circ} 18^{\prime} \mathrm{W}\right)$. Dates rapid alluviation in tributary valley in response to ice advance of Itkillik II age down John Valley (Hamilton and Porter, 1975). Coll and subm 1977 by T D Hamilton.

\section{USGS-162. Wind River Valley}

$>\mathbf{3 8 , 0 0 0}$ $\mathrm{S}$ of continental 年 age on last major glacial advance in Wind Valley. Coll and subm in 1976 by T D Hamilton. 


\section{USGS-229. Wind River Valley}

$$
10,500 \pm 80
$$

Detrital wood $9 \mathrm{~m}$ below surface of lacustrine plain, $\mathbf{E}$ side Wind $\mathbf{R}$

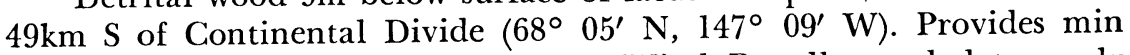
limiting age on deglaciation of upper Wind $R$ valley and dates early phase of postglacial alluviation. Coll and subm 1976 by T D Hamilton.

\section{USGS-163. Wind River Valley}

$$
9600 \pm 90
$$

Wood $9.5 \mathrm{~m}$ below surface of lacustrine plain, E side Wind $\mathrm{R} 43 \mathrm{~km}$ $\mathrm{S}$ of Continental Divide $\left(68^{\circ} 08^{\prime} \mathrm{N}, 147^{\circ} 14^{\prime} \mathrm{W}\right)$. Provides min limiting age on late glacial outwash deposition in upper $W$ ind $R$ valley and antedates postglacial lacustrine episode. Coll and subm 1976 by T D Hamilton.

\section{USGS-164. Wind River Valley}

$9730 \pm 230$

Est $\delta^{13} C=-25 \%$ o

Detrital wood $15 \mathrm{~m}$ below surface of lacustrine plain, $\mathbf{E}$ side Wind $\mathbf{R}$

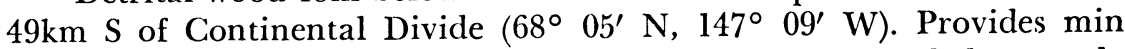
limiting date on deglaciation of upper Wind $\mathrm{R}$ valley and dates early phase of postglacial alluviation. Coll and subm 1976 by T D Hamilton.

\section{USGS-165. Itkillik Valley}

$\mathbf{4 3 0} \pm \mathbf{5 0}$

Roots in growth position in permanently frozen sand, $3.5 \mathrm{~m}$ below surface of cutbank, W side Itkillik R $5 \mathrm{~km}$ NW of Itkillik Lake $\left(68^{\circ} 27^{\prime}\right.$ $\left.\mathrm{N}, 149^{\circ} 59^{\prime} \mathrm{W}\right)$. Dates late Holocene episode of river alluviation. Coll and subm by $\mathrm{T} \mathrm{D}$ Hamilton.

\section{USGS-166. Itkillik Valley, Alaska}

$$
770 \pm 130
$$

Willow roots in growth position in permanantly frozen sand, $1.5 \mathrm{~m}$ below surface of cutbank, W side Itkillik R $5 \mathrm{~km} \mathrm{NW}$ of Itkillik Lake $\left(68^{\circ} 27^{\prime} \mathrm{N}, 149^{\circ} 59^{\prime} \mathrm{W}\right)$. Dates late Holocene episode of river alluviation and formation of $6.5 \mathrm{~m}$ terrace. Coll and subm by $\mathrm{T} D$ Hamilton

\section{USGS-167. Twin Lakes}

$>42,500$

Est $\delta^{13} C=-25 \%$ o

Wood from diamicton $27 \mathrm{~m}$ below surface of river bluff, W side Phoebe Creek 1.5km upstream from Robert Creek $\left(67^{\circ} 35^{\prime} \mathrm{N}, 149^{\circ} 13^{\prime}\right.$ W). Provides max limiting age on last major glacial advance in Chandalar Valley system. Coll and subm by $\mathrm{T} \mathrm{D}$ Hamilton.

\section{Ballaine Lake series}

Sample coll in trench excavated into ice-wedge system $1 \mathrm{~km} \mathbf{E}$ of Ballaine Lake, near Fairbanks $\left(64^{\circ} 52^{\prime} \mathrm{N}, 147^{\circ} 48^{\prime} \mathrm{W}\right)$. Coll 1969 and subm 1975 by T D Hamilton. 
USGS-219.

$300 \pm 40$

Fibrous peat $0.3 \mathrm{~m}$ below surface. Postdates episode of ice-wedge melting that followed early Neoglacial growth.

\section{USGS-335.}

$320 \pm 60$

Peat from trough above active ice wedge. Provides min limiting age on earlier episode of wedge growth followed by thaw. Dates beginning of latest phase of wedge activity, which continues to present.

USGS-77.

$\mathbf{1 3 8 0} \pm \mathbf{5 0}$

Coarse fibrous sedge peat $0.4 \mathrm{~m}$ below surface. Dates episode of icewedge melting that followed early Neoglacial growth.

USGS-31.

$1770 \pm 70$

Sedge or grass peat $0.5 \mathrm{~m}$ below surface. Dates epiode of melting that followed early Neoglacial growth.

USGS-75.

$1990 \pm 80$

Coarse woody peat $0.5 \mathrm{~m}$ below surface. Dates cessation of episode of early Neoglacial ice-wedge growth.

USGS-30.

$3110 \pm 100$

Coarse woody peat $0.7 \mathrm{~m}$ below surface. Dates cessation of episode of early Neoglacial ice-wedge growth.

USGS-78.

$3090 \pm 170$

Est $\delta^{13} C=-25 \%$ early Neoglacial ice-wedge growth.

USGS-76B.

$3440 \pm 60$

Coarse woody peat $1.7 \mathrm{~m}$ below surface. Dates cessation of episode of early Neoglacial ice-wedge growth.

\section{USGS-47. Sagavanirktok Valley}

$12,840 \pm 160$

Grass, sedge, and wood fragments $16 \mathrm{~m}$ below surface of $\mathrm{W}$ side Sagavanirktok R $3.1 \mathrm{~km}$ S of Atigun R confluence $\left(68^{\circ} 29.5^{\prime} \mathrm{N}\right.$, $\left.149^{\circ} 01^{\prime} \mathrm{W}\right)$. Provides close min limiting date on glacier retreat from upper Sagavanirktok Valley. Coll and subm 1975 by T D Hamilton.

\section{USGS-161. Teklanika Valley}

$12,300 \pm 120$

Wood fragments at base of kettle flling 8. river bluft

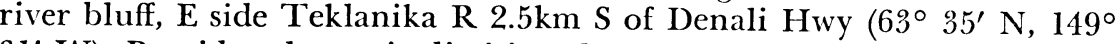
$\left.31^{\prime} \mathrm{W}\right)$. Provides close min limiting date on glacier retreat from upper Teklanika Valley. Coll and subm in 1976 by T D Hamilton. 
USGS-41. Chandalar River near Caro

Est $\delta^{13} C=-25 \%$

Spruce wood from buried forest bed $2 \mathrm{~m}$ below surface in river bluff $1 \mathrm{~km}$ downstream from Caro $\left(67^{\circ} 10.5^{\prime} \mathrm{N}, 147^{\circ} 59^{\prime} \mathrm{W}\right)$. Overlies outwash correlated with Itkillik I glaciation of central Brooks Range; underlies loess of probable Itkillik II age. Coll and subm 1975 by T D Hamilton.

\section{USGS-43. Galbraith Lake}

$3160 \pm 80$

Bryophytic peat $10.5 \mathrm{~m}$ below surface of lacustrine plain, $\mathrm{E}$ bank Atigun R $4 \mathrm{~km}$ S of Galbraith Lake $\left(68^{\circ} 25.5^{\prime} \mathrm{N}, 149^{\circ} 23^{\prime} \mathrm{W}\right)$. Dates episode of alluviation following high stand of Galbraith Lake. Coll and subm 1975 by $T$ D Hamilton.

\section{USGS-45. Wiseman \\ $8430 \pm 70$}

Peaty muck $2 \mathrm{~m}$ below surface in roadcut along Alyeska Haul Rd $1 \mathrm{~km} \mathrm{~S}$ of Minnie Creek $\left(67^{\circ} 25^{\prime} \mathrm{N}, 150^{\circ} 04^{\prime} \mathrm{W}\right)$. Provides min limiting date on glacier retreat from Middle Fork, Koyukuk Valley, and max limiting date on probable major landslide. Coll and subm 1975 by $\mathrm{T} D$ Hamilton.

\section{USGS-290. Kogru River Dewline, Alaska}

$\mathbf{3 8 , 0 0 0} \pm \mathbf{5 0 0}$ Est $\delta^{1 s} C=0 \%$

Shell fragments of shallow-water marine mollusks from low, eroding mounds on tundra near Kogru R Dewline site, N Alaska $\left(70^{\circ} 34^{\prime} \mathrm{N}\right.$, $152^{\circ} 22^{\prime} \mathrm{W}$ ). Radiocarbon detected in this sample is probably due to contamination processes (Robinson, 1979). Date, therefore, indicates lower limit of termination of marine deposition for Gubik Formation at the site. Coll and subm by Erk Reimnitz, USGS.

\section{Colville River Delta series}

Thin peaty layers from core taken on Colville R Delta front. Dates document low rates of deposition characteristic of arctic deltas. Coll and subm 1976 by Erk Reimnitz and Peter Barnes, USGS.

USGS-292.

$3110 \pm 70$

Est $\delta^{13} C=-25 \%$ o

140 to $145 \mathrm{~cm}$ below sea floor at $1 \mathrm{~m}$ water depth Vibrocore $23\left(70^{\circ}\right.$ $\left.29.5^{\prime} \mathrm{N}, 150^{\circ} 59.5^{\prime} \mathrm{W}\right)$.

USGS-291.

$3430 \pm 45$

130 to $133 \mathrm{~cm}$ below sea floor at $1 \mathrm{~m}$ water depth Vibrocore $23\left(70^{\circ}\right.$ $\left.29.5^{\prime} \mathrm{N}, 150^{\circ} 59.5^{\prime} \mathrm{W}\right)$.

USGS-294.

$$
2270 \pm 60
$$

$58 \mathrm{~cm}$ below sea floor at $3.3 \mathrm{~m}$ water depth Vibrocore $18\left(70^{\circ} 33.2^{\prime}\right.$ $\left.\mathrm{N}, 150^{\circ} 27.9^{\prime} \mathrm{W}\right)$. 
$3040 \pm 50$

USGS-293.

Est $\delta^{13} \mathrm{C}=-25 \%$

97 to $98 \mathrm{~cm}$ below sea floor at $3.3 \mathrm{~m}$ water depth Vibrocore $18\left(70^{\circ}\right.$ $\left.33.2^{\prime} \mathrm{N}, 150^{\circ} 27.9^{\prime} \mathrm{W}\right)$.

Nevada

\section{Las Vegas Wash series}

Cattail peat laminae intercalated with silt and sand ca $3 \mathrm{~m}$ below stream terrace formed by rapidly entrenching Las Vegas Wash $\left(36^{\circ} 06^{\prime}\right.$ $\left.\mathrm{N}, 114^{\circ} 57^{\prime} \mathrm{W}\right)$. USGS-92 and -93 together indicate recent episode of extensive marsh develpoment. Dates coincide with either activities caused by humans such as increased water discharge or localized debris dams resulting from flash floods. Coll 1976 by $\mathrm{F}$ W Bachhuber, Univ Nevada, Las Vegas; subm by M C Blake, USGS.

USGS-92. Las Vegas Wash

USGS-93. Las Vegas Wash

Oregon

$$
\begin{array}{r}
\text { Modern } \\
\text { Est } \delta^{13} C=-25 \% \\
\text { Modern } \\
\text { Est } \delta^{13} C=-25 \%
\end{array}
$$

$6090 \pm 60$

USGS-105. North Summit Flow, Newberry Crater Est $\delta^{13} C=-25 \%$

Charcoal from within tree mold ca $1 \mathrm{~km} \mathrm{~N}$ of rim of Newberry Crater $\left(43^{\circ} 45.2^{\prime} \mathrm{N}, 121^{\circ} 144^{\circ} \mathrm{W}\right)$. Dates eruption from NW rift zone high on flank of Newberry Crater. Coll 1976 by Norm MacLoed, USGS; subm by Duane Champion, USGS.

\section{USGS-106. Sugar Pine Butte Flow, Newberry Est $\begin{array}{r}5870 \pm 60 \\ { }^{1 s} C=-25 \% \text { 。 }\end{array}$ Crater}

Charcoal from within tree mold $1 \mathrm{~km} \mathrm{~W}$ of Sugar Pine Butte $\left(43^{\circ}\right.$ $49.5^{\prime} \mathrm{N}, 121^{\circ} 22^{\prime} \mathrm{W}$ ). Dates eruption of flow mantling W side of Sugar Pine Butte and flow to W. Coll 1976 by E M Shoemaker and Duane Champion, USGS; subm by Duane Champion.

\section{USGS-107. Lava Butte, Newberry Crater Est $\delta^{13} C=-25 \%$}

Charcoal from beneath $4.8 \mathrm{~m}$ basaltic cinders from Lava Butte in hwy outcrop of US $97 \mathrm{ca} 1 \mathrm{~km} \mathrm{NE}$ of Lava Butte Lookout $\left(43^{\circ} 55.5^{\prime} \mathrm{N}\right.$, $121^{\circ} \mathrm{W}$ ). Dates eruption of Lava Butte cinders and probably large flow to W. Coll 1976 by Larry Chitwood and Robert Jensen, US Forest Service; subm by Duane Champion.

Venezuela

Taima-taima Early Man site

USGS-247.

$13,880 \pm 120$

Est $\delta^{13} \mathrm{C}=-25 \%$

Twigs, evidently masticated, assoc with mastodon slain and butchered by El Jobo hunters. Saturated gray sand (Unit 1) of Taima-taima 
Survey, Menlo Park, California, Radiocarbon Measurements II 321

$\left(11^{\circ} 30^{\prime} \mathrm{N}, 69^{\circ} 35^{\prime} \mathrm{W}\right)$. Earliest dated kill site in W hemisphere (Bryan et al, 1978). Coll and subm by A L Bryan, Univ Alberta. Received standard pretreatment.

\section{USGS-247A.}

$13,830 \pm 120$

Est $\delta^{13} C=-25 \%$ 。

Repeat of USGS-247. Leached twice in $0.5 \mathrm{~N} \mathrm{NaOH}\left(16 \mathrm{hr}\right.$ at $\left.60^{\circ} \mathrm{C}\right)$. Insoluble fraction.

USGS-247B.

$13,650 \pm 120$

$\mathrm{NaOH}$ soluble fraction of above.

Est $\delta^{13} C=-25 \%$

\section{REFERENCES}

Barnes, P W and Hopkins, D M, eds, 1978, Geological sciences, in Environmental assessment of the Alaskan Continental Shelf: Boulder, Colorado, Natl Oceanog Atmos Admin and US Bur Land Management, p 101-133.

Berger, Rainer, Taylor, R E, and Libby, W F, 1966 Radiocarbon content of marine ,

Bryan, A L, Casamiquela, R M, Cruxent, J J, Grahn, Ruth, and Oshsnius, Caludio, 1978, An El Jobo mastodon kill at Taima-taima, Venezuela: Science, v 200, p $1275-1277$.

Carter, L D and Robinson, S W, 1978, Radiocarbon-dated episodes of activity and stabilization of large dunes, Arctic Coastal Plain, Alaska (abs): Am Quaternary Assoc Abs Biennial Mtg, 5th, Sept 2-4, 1978, Edmonton, Alberta, p 192.

Assoc Abs Bine Meyer, 1972, Holocene activity of the Coyote Creek fault as recorded in sediments of Lake Cahuilla, in The Borrego Mountain earthquake of April 9, 1968: USGS Prof Paper 787, p 112-130.

Hamilton, T D, 1979, Quaternary stratigraphic sections with radiocarbon dates, Chandalar quadrangle, Alaska: US Geol Survey open-file rept 79-751, $10 \mathrm{p}$

Hamilton, T D and Porter, S C, 1975, Itkillik glaciation in the Broosk Range, northern Alaska: Quaternary Research, v 5, p 471-497.

Heat Natl Oceanog Atmos Admin, environmental assessment Alaskan Continental Shelf, ann repts principal investigators, March 1977, v 16, p 396-518.

Hopkins, D $M$ and Hartz, $R$ M, in press, Offshore permafrost studies, Beaufort Sea: Natl Oceanog Atmos Admin, environmental assessment Alaskan Continental Shelf, ann repts principal investigators, March 1978, in press.

Hoskins, C W, ms, 1957, Paleoecology and correlation of the lowest emergent California marine terrace, from San Clemente to Half Moon Bay: PhD dissert, Dept Geol, Stanford Univ, $108 \mathrm{p}$.

Osterkamp, T E and Harrison, W D, 1976, Subsea permafrost at Prudhoe Bay, Alaska; drilling report: Univ Alaska Geophys Inst Sea Grant rept 76-5, 69 p.

Robinson, S W, 1977, US Geological Survey, Menlo Park, California radiocarbon measurements I: Radiocarbon, v 19, p 460-464.

Robinson, S W, 1979, Radiocarbon dating of pre-Holocene carbonate materials: Geol Soc America, Abs with programs, v 11, p 504

Robinson, S W and Thompson, Gail, in press, Radiocarbon corrections for marine shell dates with application to southern Northwest Coast prehistory: Syesis, in

press.
Sellmann, $\mathrm{P}$ V and Chamberlain, E J, in press, Delineation and engineering characteristics of permafrost bencath the Beaufort Sea: Natl Oceanog Atmos Admin, environmental assessment Alaskan Continental Shelf, ann repts principal investigators, March 1978, in press.

Sieh, K E, 1978, Prehistoric large earthquakes produced by slip on the San Andreas fault at Pallet Creek, California: Jour Geophys Research, v 83, p 3907-3939.

Stuiver, Minze and Polach, H A, 1977, Discussion: Reporting of ${ }^{14} \mathrm{C}$ data: Radiocarbon, v 19, p 355-363. 